Proceedings

\title{
Changes in Algal Species Composition of Alpine Lake Nesamovyte (Eastern Carpathians, Ukraine) from 100 Years Ago to Present ${ }^{\dagger}$
}

\author{
Petro M. Tsarenko ${ }^{1}$, Olena P. Bilous ${ }^{2, *}$, Olha M. Kryvosheia-Zakharova ${ }^{1}$, Halyna H. Lilitska ${ }^{1}$, Yuriy Malakhov ${ }^{3}$ \\ and Janne Soininen ${ }^{4}$
}

Citation: Tsarenko, P.M.; Bilous, O.P.; Kryvosheia-Zakharova, O.M.; Lilitska, H.H.; Malakhov, Y.; Soininen, J. Changes in Algal Species Composition of Alpine Lake Nesamovyte (Eastern Carpathians, Ukraine) from 100 Years Ago to Present. 2021, 68, x.

https://doi.org/10.3390/xxxxx

Published: date

Publisher's Note: MDPI stays neutral with regard to jurisdictional claims in published maps and institutional affiliations.

Copyright: (C) 2021 by the authors. Submitted for possible open access publication under the terms and conditions of the Creative Commons Attribution (CC BY) license (http://creativecommons.org/licenses/by/4.0/).
1 M.G. Kholodny Institute of Botany, National Academy of Sciences of Ukraine, Tereschenkivska Str. 2, 01004 Kyiv, Ukraine; ptsar@ukr.net (P.M.T.); olha_krivosheia@ukr.net (O.M.K-Z.); dunaliella@ukr.net (H.H.L.)

2 Institute of Hydrobiology, NAS of Ukraine, Geroiv Stalingrada 12, 04210 Kyiv, Ukraine

3 Ecocare Ukraine, Kyiv, Ukraine; yur.malakhov@gmail.com

4 Department of Geosciences and Geography, University of Helsinki, 00100 Helsinki, Finland; janne.soininen@helsinki.fi

* Correspondence: bilous_olena@ukr.net

+ Presented at the 1st International Electronic Conference on Biological Diversity, Ecology and Evolution, 1531 March 2021; Available online: https://bdee2021.sciforum.net/.

\begin{abstract}
The species diversity of algae in different ecotopes of the alpine lake Nesamovyte was studied. In total, 233 species were identified comprising globally and regionally rare species. We also documented a temporal change in species composition from the first investigations conducted 100 years ago to present. An increase in the species diversity of Bacillariophyta and Chlorophyta, the constancy of the number of Euglenophyta and Cyanoprocaryota species, a decrease in the composition of Charophyta and the disappearance of Dinophyta species were revealed. We further documented some changes in the most abundant species and indicator species for certain limnological conditions, the disappearance of montane species and the colonization of species with a wide ecologicalgeographical amplitude. Benthic and plankton-benthic conditions became dominant and indicators of low-alkaline mesotrophic waters as well as mass development ("blooming") of some species increased. The studied features of the species diversity of the "algoflora" indicate high species richness and high number of indicator species, as well as lake ecosystem degradation and an increase in organic pollution. Overall, there was a shift of the lake from oligotrophic to mesotrophic state, as indicated by certain algal groups. The noted changes in the species diversity of algae in Lake Nesamovyte could be attributed to the increased anthropogenic influence leading to change of the trophic status of the lake.
\end{abstract}

Keywords: algae; diversity; Eastern Carpathians; mountains lakes; ecosystems; Nesamovyte

\section{Introduction}

Lakes of the Carpathian mountain system have a rich and distinctive biodiversity of algae and algal communities. They constitute an integral part of the highland landscape, serve as a core algae habitat in the region, and as a shelter for rare and characteristic algal taxa [1-5]. At the end of 20th century, the alpine lake algal biodiversity was actively studied in the western part of the Carpathians (Carpathian-Tatra region). However, much less is known about the species composition and taxonomic structure of the algal flora in the analogous Eastern Carpathian lakes [6]. In this study, we summarise the data from the three stages of algal biodiversity research in one the high-elevation lakes in the Eastern Carpathians-Lake Nesamovyte. First, we conduct a comparative analysis of the changes in algal biodiversity that span a period of more than one hundred years [7-10]. We then characterise 
these changes by analysing bioindicator species and establish the main ecological features of Lake Nesamovyte algal flora.

\section{Materials and Methods}

Lake Nesamovyte is a part of glacial cirque valley and has a glacial erosion origin. It is a part of the Carpathian-Danube algofloristic sub-province within the algofloristic zoning of Ukraine classification scheme [11]. It is located on the southern-western slope of Mt Tur$\mathrm{kul}$, at the altitude of $1748 \mathrm{~m}$ (Figure 1). It has an area of 0.3 ha and a maximum depth of $2 \mathrm{~m}$ (Table 1). It is mainly fed by atmospheric water supply and has a $\beta$-mesosaprobic water quality status [4]. It is a well-known natural object of the Ukrainian Carpathians and a part of Carpatsky National Park.

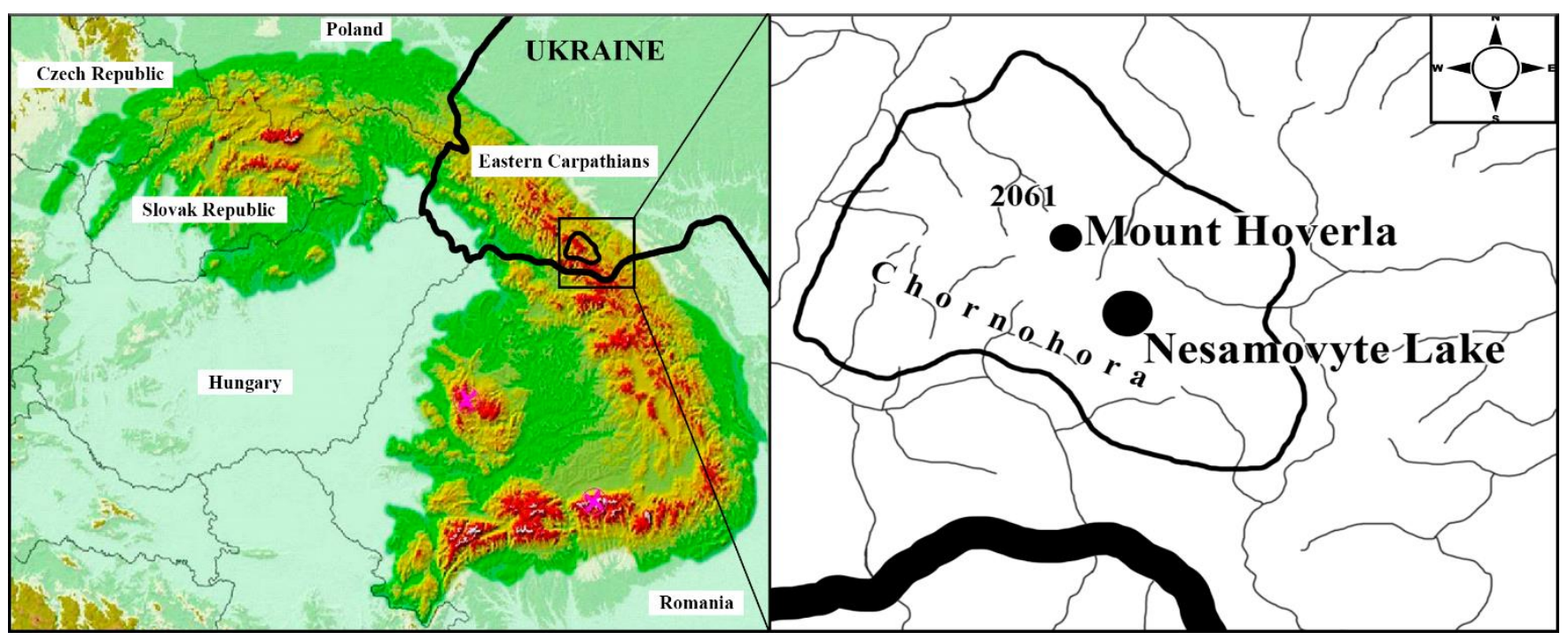

Figure 1. Map of the Carpathian region and the location of the lake Nesamovyte.

Table 1. Morphometry and basic physic-chemical water parameters of Nesamovyte Lake (original measurements).

\begin{tabular}{|c|c|c|c|c|c|c|c|}
\hline $\begin{array}{c}\text { Location } \\
\text { (Coordinates) }\end{array}$ & $\begin{array}{l}\text { Altitude } \\
\text { a.s.l., } \mathrm{m}\end{array}$ & Surface, ha & Depth Max., m & $\begin{array}{c}\text { Temperature } \\
\mathrm{H}_{2} \mathrm{O}\end{array}$ & $\mathrm{pH}$ & $\begin{array}{c}\text { Conductivity, } \\
\mu \mathrm{S} / \mathrm{cm}\end{array}$ & $\mathrm{dO}_{2}, \mathrm{mg} / \mathrm{L}$ \\
\hline $\begin{array}{l}48^{\circ} 07^{\prime} 36.6^{\prime \prime} \mathrm{N} \\
24^{\circ} 32^{\prime} 26.4^{\prime \prime} \mathrm{E}\end{array}$ & 1748 & 0.3 & $\sim 2.0$ & $18.3(16.2)$ & $6.2-6.4$ & $5.1-6.0$ & 10.7 \\
\hline
\end{tabular}

Our study is based on the original samples collected from different ecotopes of Lake Nesamovyte (plankton, benthos, periphython, squeezes from the moss) in 2013-2018. We also analysed historical samples (fixed in 4\% formaldehyde) of 1967 that are stored in the collection of M.G. Kholodny Institute of Botany NAS of Ukraine (collection acronym: KWA). Taxonomic identification was done after consulting the following references [12-19]. The samples were studied by means light and scanning electron (SE) microscopy. Diatom identification was done using the $35 \% \mathrm{H}_{2} \mathrm{O}_{2}$ treated frustules material [20]. SE microscopy was done on the JEOL-1230 microscope in the Centre of Electron Microscopy, M.G. Kholodny Institute of Botany NAS of Ukraine. Some of the species were identified after live samples cultivation on liquid and agarised Bold's media. Image processing was done in Axiovision 4.3.7. and GIMP 2.8.10 packages. Identified taxa were validated using the AlgaeBase system [21] and "Algae of Ukraine ..." [22] monographic series.

Ecological bioindicator species analysis was based both on the historical data (19101920 and 1967-1978 collections) and on the results of original studies (2013-2021). It was based on the following individual algae species characteristics: habitat type, flow velocity, oxygen saturation, $\mathrm{pH}$, salinity, general trophic status and the level of organics pollution [23-28]. 


\section{Results and Discussion}

Overall, 233 algae species (including 245 infraspecific taxa, inft) were found in Lake Nesamovyte over a hundred-year period. These species belong to eight taxonomic groups, 15 classes, 33 orders, 55 families, and 99 genera of cyanobacteria and algae (Table 2).

Bacillariophyta and Charophyta form the basis of this diversity, accounting for about $57 \%$ of the genera richness and $84 \%$ of the species and intraspecific richness of algae of all ecotopes. The diversity of Chlorophyta and Euglenozoa is relatively low (ca. 4.9-5.7\% of the taxonomic list), and the diversity of Cyanobacteria and Ochrophyta is even lower-near 1.7\% of the taxonomic list on average. Finally, the diversity of Cryptophyta and Miozoa accounted for less than $1 \%$ of the total taxonomic list (Figure 1). The dominant algal orders were-Desmidiales (15 genera-66 species-75 inft), Naviculales (10 genera-50 species), Cymbellales (525), Achnanthales (5-11), Eunotiales (1-11), Sphaeropleales (6-7), Fragillariales (4-9), Zygnematales (6-6) and Euglenidida (2-5). Together, these orders account for $56 \%$ of the genera and species composition of Lake Nesamovyte algal biodiversity. The dominant genera of the lake's algal flora were Staurastrum (21-22 inft), Pinnularia (14-16), Euastrum (12-15), Navicula (12), Cosmarium (12), Eunotia (11), Gomphonema (10), Encyonema (5), Planothidium (5) and Closterium (4). These 10 genera account for almost a half (44.5\%) of all species composition. At the same time, nearly $60 \%$ of algal genera of the lake were monotypic, i.e., represented by a single species.

This taxonomic structure represents a generalization of the 100 years research of Lake Nesamovyte algal biodiversity studies [6-8,10,29-31]. The comparative analysis of the taxonomic data from the three phycological research stages-early 20th century, middle of the 20 th century, and early 21st century-shows a gradual change the lake algal biodiversity. This is evident on the high, taxonomic groups, level, and especially remarkable on the lower, genera diversity, level (Figure 2).

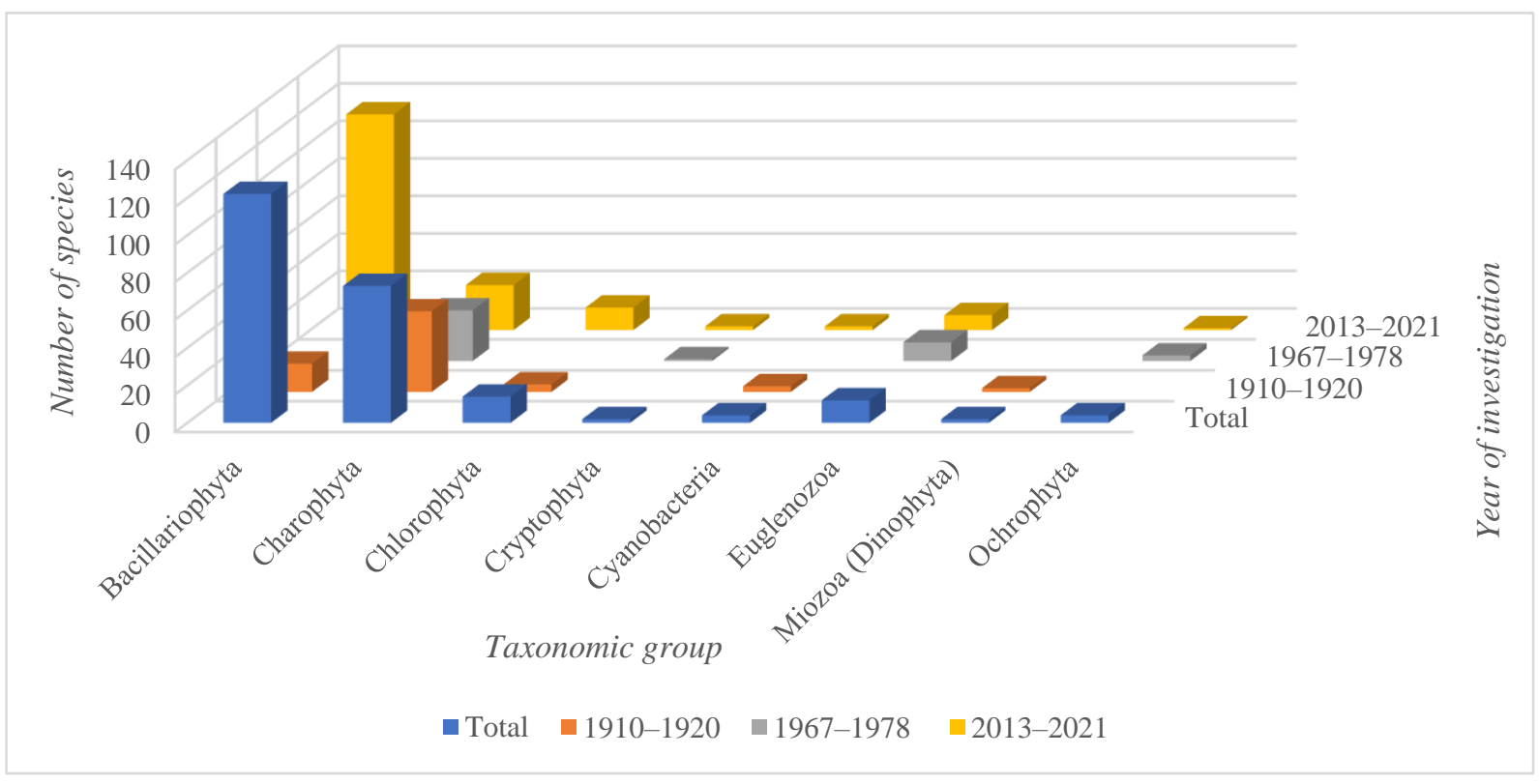

Figure 2. Species composition of algae in Lake Nesamovyte (split by taxonomic groups and three stages of research in 1910-2021).

The change of dominating taxonomic groups of algae in terms of species richnessfrom Charophyta (Desmidiales) and diatom algae (together $87 \%$ of the total species composition) is established for the period 1910-1920 [7]. The specific high impact Desmidiales $(\sim 58 \%)$ is maintained along with the emergence of representatives of Euglenozoa ( 15\%) and flagellated algae-Cryptophyta and Ochrophyta ( 2-5\%) in 1967-1978 [6,9], and nowextremely high rates are noted for Bacillariophyta (115 species-117 inft, or $\sim 70 \%$ ), much lower-Charophyta ( 15\%), Chlorophyta $(\sim 7.3 \%)$ and Euglenozoa ( 5.0), low for Cryptophyta 
$(>1 \%)$ and Cyanobacteria $(>1 \%)$ and absence of Dinophyta. A high variety of modern species composition has been established for Bacillariophyta [31] sharply contrasting (sevenfold increase) with the literature data [7]. The high role of the diversity and composition of this group for "flora" of Lake Nesamovyte has been noted. The following genera are characterized by high species diversity: Pinnularia (12.1\%), Navicula (9.5\%), Eunotia (8.6\%), Gomphonema (8.6\%), Encyonema (4.3\%). The typical diatom species in different ecotopes of the lake were Tabellaria flocculosa (Roth) Kützing, Eunotia minor (Kützing) Grunow and Frustulia crassinervia (Brébisson) Lange-Bertalot et Krammer (4-5-according to Starmach scale [32]. At the same time, the regionally rare species for the flora of Ukraine were found (Cymbella lange-bertalotii Krammer, Encyonema neogracile Krammer, Eunotia tetraodon Ehrenberg, Pinnularia macilenta Ehrenberg etc.), and also Pinnularia falaiseana Krammer, which has a pronounced disjunctive distribution in the world representing a rare species. The current high diversity of Bacillariophyta in the lake is probably partly due to the intensive study of diatoms in the lake flora. Apparently, this can also be influenced by a set of ecological and geographical reasons, in particular with the possible settlement of widespread forms and invasive species of plain areas. Likewise, the presence of European and regionally rare species of Bacillariophyta is an additional argument for the protection of the ecosystem of Lake Nesamovyte and its diversity as a habitat for their existence.

Original studies of the diversity of the green phylum of the algae flora (Charophyta and Chlorophyta) of this waterbody confirm the richness and floristic significance in the lake ecosystem (Figure 2) and show a decrease in the species diversity of Charophyta (from 43 species (45 inft) in 1920 to 27 (31)-in 1967-1978 and till 24 (25) nowadays), as well as growth-Chlorophyta (4 species-12 species, respectively 1910-2021) [6]. The representatives of Zygnemaphyceae (14.6\%) and Chlorophyceae (7.3\%) classes comprise about one-fifth of the total algal species of Lake Nesamovyte nowadays. A significant role in the formation of this diversity belongs to the order Desmidiales (11.6\%), however the species richness of Zygnematales and Sphaeropleales-insignificant and is at the level of $3.7 \%$ and 3.0\%, respectively. Among genera by species diversity stand out Euastrum and Staurodesmus (5 species-3.0\%, each of them). 18 genera are presented only by one species each. In turn, compared to the beginning of the 20th century, the presence of six genera has not been confirmed, and from 1967-1978-four genera. Also, for modern period of investigations, the rare species from genera Hyalotheca, Euastrum and Tetmemorus, that are typical for the flora of waterbodies in mountain regions are revealed. In addition to rare forms, for the first time the presence of filamentous Charophyta algae and mucilage-forming coccoid and flagellar green algae was noted (Mougeotia, Spirogyra, Zygnema, Oedogonium, Botryococcus, Chlamydomonas, Mucidosphaerium, Chlorella, Mychonastes, Westella). These findings indicate the probable degradation of the alpine ecosystem from oligotrophic waterbody in the early $20^{\text {th }}$ century into its transformed status to mesotrophic type and settlement of its ecotopes by common species with a wide ecological amplitude $[4,6,33]$.

According to the results of comparative analysis of species composition Charophyta of Lake Nesamovyte for 100-year period [7] a change in the complex of leading species by quantitative indicators (=frequency of occurrence) was noted for Desmidiales/Zygnematales, namely: from communities of Cylindrocystis brebissonii (Ralfs) De Bary, Actinotaenium cucurbita (Brébisson ex Ralfs) Teiling ex Rủžička, Cosmarium staurastriforme Gutwinski, C. venustum (Brébisson) W. Archer var. excavatum (Eichler et Gutwinski) West et G.S. West, Euastrum insigne Hassall ex Ralfs and others, to the similar in the 60-70s of the 20th century [9]-Staurastrum senarium f. senarium and f. tatricum Raciborski, Euastrum pinnatum Ralfs and others, and modern composition of this species-Hyalotheca dissiliens Brébisson ex Ralfs, Netrium digitus (Ehrenberg ex Ralfs) Itzigsohn et Rothe emend. Ohtani, Euastrum humerosum Ralfs var. affine (Ralfs) Raciborski, E. ansatum Ehrenberg ex Ralfs and Staurastrum polytrichum (Perty) Rabenhorst.

The striking manifestation of the instability of the ecological state of the lake, violation of its ecosystem and increasing of its trophic level is the process of "blooming" of the water of this reservoir, due to the massive development of green colonial coccoid algae 
Botryococcus terribilis Komarek et Marvan (Trebouxiales, Trebouxiophyceae), which was highlighted in the summer of 2015 for the first time [6].

The initial investigations revealed the affinity of the mountain-"alpine" part of the species composition of the studied "flora" for the Carpathian lakes with the similar lakes of the Tatra, Sudeten and Alps and the presence of specific 27 alpine holarctic species of desmidiaceen and coccoid green algae [7]. However, the current studies of the algal species diversity of the lake do not confirm the presence of the majority of the species composition (over $80 \%$ ) observed in the 20-s of 20th century of alpine flora of the Alpine-Carpathian region. However, the presence of another complex of conditionally arctic algae species, including diatoms (Cavinula pseudoscutiformis (Hustedt) D.G. Mann \& Stickle, P. obscura Krasske, P. rhombarea Krammer, P. rupestris Hantzsch, P. subanglica Krammer, P. subrupestris Krammer) were revealed.

The ecological analysis is conducted based on types of indicators, which are grouped based on following characteristics: habitat preference, streaming and oxygenation, $\mathrm{pH}$, salinity, trophic state, organic pollution (class of water quality) [26]. With the help of ecological preferences of species that were grouped for time intervals (I-1910-1920; II1967-1978; III-2013-2021), we present the ecological characteristics (on the example of indicators of trophic and saprobity of the lake) of these periods. The trophic state of the lake is characterized on the basis of characteristics of $55.6-64.7 \%$ taxa from the total amount indicated for each time period. There is a tendency of changing the number of indicator species from oligo-mesotraphentic (o-m) $-48.8 \%$ from the total amount of indicator species characterizing the minimal trophic level of the Lake (20-ies of 20th century) to prevailing of mesotraphentic $(\mathrm{m})$ indicator species $(48 \%)$. However, the meaningful role oligo-mesotraphentic (o-m) (44\%) indicator species in between 60-es of 20th century is maintained. The forming of oligo-mesotraphentic (o-m) (24.1\%), meso-eutraphentic (me) $23.1 \%$ and oligotraphentic (ot) $(22.2 \%)$ indicator species along with the emergence of hypereutraphetic (he) and increasing the amount of eutraphetic (e) indicators is embracing for modern period of investigations. The presence of these species nowad ays characterizes the general trend of deterioration of the trophic status of the studied reservoir.

Peculiarities of water saprobity indicators (54.3-70.7\% of species composition), as well as saprobity indices allowed to characterize an organic pollution and to correlate these data with the classification adopted in Ukraine, highlighting water quality classes [34]. Comparative analysis of the number of indicator species of quality class I varies from $44.7 \%$ (1910-1920) to $39.3 \%$ and the emerging of indicators of class IV water quality, which indicates a tendency to deterioration of the water status and increasing of organic pollution (1967-1978). And in the modern period - also the predominance of indicators of class II water quality (39\%) and the presence of indicators of class IV quality. Thus, we observe a gradual increase in organic pollution of the reservoir from 1920 to the present period.

\section{Conclusions}

As a result of studying the algal species composition of Lake Nesamovyte during 100 -year period of investigations, the 233 species ( $245 \mathrm{inft}$ ) composing 8 taxonomic groups, 15 classes, 33 orders, 55 families, 99 genera were revealed. Modern species diversity of algae is over $70 \%$ of the total number of species. During the compared period, significant structural changes in the taxonomic composition of the algoflora of the lake, as well as complexes of dominant species and their diversity were noted. The basis of taxonomic and species diversity of the waterbody is formed by Bacillariophyta and Charophyta, which combine more than half of the genera level and more than $2 / 3$ of the species and intraspecific composition of algae. The diversity of Chlorophyta and Euglenozoa were insignificant (about 5\%), for Cyanobacteria and Ochrophyta-quite low (less than 2\%). The representatives of Miozoa according to the materials of modern research was not revealed. The modern species composition of algae in Lake Nesamovyte is characterized by the presence of a 
significant number of regionally rare species and is an additional argument for the protection of the ecosystem of the reservoir and the preservation of the specific species composition.

On the basis of the ecological characteristics of algae, an ecological analysis of the species composition of the lake was carried out. Its results showed a number of changes that took place with the ecosystem of the lake in different historical periods 1910-2021. In particular, the indication of the habitat preferences reaffirmed the hydrological changes in the Lake. The indication of the $\mathrm{pH}$ confirmed this conclusion, and moreover, decreasing the leading group of acidophil algae, indicating the presence among the species composition of the "bog component" of flora, and the increase in the role of indicator indifferents in the modern period, testified not only hydrological changes in the lake, but also ecological changes that have occurred with the ecosystem in Lake Nesamovyte. The analysis of the trophic state indicators, namely the presence of hypereutraphentic (he) taxa in modern period of investigations, in comparison with the previous period (1967-1978), as well as increasing amount of eutraphentic (e) indicators in comparison with the earliest period (1910-1920), characterizes the deterioration of the current trophic state of the investigated Lake. The analysed indicators of saprobity in the Lake indicate a change in organic pollution at the present stage, with a change in the class of water quality from I to II class with the occurrence of IV class indicators, which were not noted in 1910-1920. Thus, it becomes obvious that the ecosystem of Lake Nesamovyte is undergoing changes, which were recorded by researchers in 1967-1978, and are aggravated today. In general, there is a tendency for the degradation of the ecosystem in Lake Nesamovyte and the deterioration of the ecological state in comparison with earlier periods.

Funding: The authors acknowledge financial and organizational support given by the administration and the employees of National Academy of Science of Ukraine.

Acknowledgments: We are grateful to associate professors V.V. Budjak and O.I. Khudyi (Yuri Fedkovych Chernivtsi University), as well as T. Mykytchak (Institute of Ecology of the Carpathians of the NAS of Ukraine, Lviv) for organizing and conducting field trips to the Ukrainian Carpathians and for assistance in the work. Our gratitude extends to J. Tunovsky (Institute of Freshwater Fish Research, Poland) for the provided hydroecological measurements.

Conflicts of Interest: The authors declare no conflict of interest.

\section{References}

1. Fott, J. (Ed.) Limnology of Mountain Lakes; Developments in Hydrobiology. Hydrobiologia, Springer: Dordrecht, The Netherlands, 1994; Volume 274. pp. 1-182, doi:10.1007/978-94-017-2095-3.

2. Cărăus, I. Algae of Romania. A Distributional Checklist of Actual Algae; Studii şi Cercetări. Biology. Universitatea din Bacău: Helsinki, Finland, 2012, 7; pp. 1-809.

3. Lenarczyk, J.; Tsarenko, P. Some rare and interesting green algae (Chlorophyta) from subalpine Tatra lakes (High Tatra Mountains, Poland). Oceanol. Hydrobiol. Stud. 2013, 42, 225-232, doi:10.2478/s13545-013-0078-7.

4. Mykitchak, T. (Ed.) Ecosystems of Lenthic Water Bodies of Chornohora Massif (Ukrainian Carpathians); ZUKS: Lviv, Ukraine, 2014; pp. 1288.

5. Ognjanova-Rumenova, N.; Wojtal, A.Z.; Sienkiewicz, E.; Botev, I.; Trichkova, T. Biodiversity of high mountain lakes in Europe with special regards to Rila Mountains (Bulgaria) and Tatra Mountains (Poland). Diatoms Fundam. Appl. 2019, 335-354, doi:10.1002/9781119370741.ch15.

6. Tsarenko, P.; Wolowski, K.; Lenarczyk, J.; Bilous, O.; Lilitska, O. Green and charophytic algae of the high-mountain Nesamovyte and Brebeneskul lakes (Eastern Carpathians, Ukraine). Plant Fungal Syst. 2019, 64, 25-32, doi:10.2478/pfs-2019-0007.

7. Wołoszyńska, J. Jeziorka czarnohorskie. Rozprawy wydz. matem.-przyrodn. PAN. Ser. B 1920, 60, 141-153.

8. Asaul, Z.I. Euglenophyta of high mountain lakes of the Ukrainian Carpathians. Ukr. Botanical J. 1969, 26, 8-13.

9. Palamar-Mordvintseva, G.M. Analisis of Desmidiales flora of the Ukrainian Carpathians. Ukr. Botanical J. 1978, 35, $29-38$.

10. Tsarenko, P.; Lilitska, H.; Kapustin, D.; Honcharenko, V. Algoflora. In Ekosystems of Lentic Water Bodies of Chornohora Massif (Ukrainian Carpathians); Mykitchak, T., Ed.; ZUKS: Lviv, Ukraine, 2014; pp. 47-60.

11. Palamar-Mordvintseva, G.M.; Tsarenko, P.M. Algofloristic zoning of Ukraine. Int. J. Algae 2015, 25, 303-328, doi:10.1615/InterJAlgae.v17.i4.10.

12. Krammer, K. Bacillariophyceae 1. Naviculaceae. In Süßwasserflora von Mitteleuropa; Gustav Fischer Verlag: Stuttgart, NY, USA, 1986; pp. 1-876. 
13. Tsarenko, P.M. Short Identification Book of Chlorococcales of the Ukraine SSR; Naukova Dumka: Kiev, Ukraine, $1990 ;$ pp. 1-208.

14. Vetrova, Z.I. Euglenofitozye vodorosli. In Flora of Algae of the Continental Water Bodies of Ukraine. 2; Lileia Press: Kiev, Ukraine, 2004; pp. 1-272. (In Russian)

15. Palamar-Mordvintseva, G.M. Flora Vodorostey Kontynentalnykh Vodoym Ukrainy; Desmidiales. 1, 2: Kyiv, Ukraine, 2005; pp. 1573. (In Ukrainian)

16. Lange-Bertalot, H.; Hofmann, G.; Werum, M. Diatomeen im Süßwasser-Benthos von Mitteleuropa; Gantner Verlag, K.-G., Ed.; Ruggell: 2011; pp. 1-908.

17. Lange-Bertalot, H.; Hofmann, G.; Werum, M.; Cantonati, M. Freshwater Benthic Diatoms of Central Europe: Over 800 Common Species Used in Ecological Assessment; Koeltz Botanical Books: Schmitten-Oberreifenberg, Germany, 2017; pp. 1-942.

18. Komarek, J.; Anagnostidis, K. Cyanoprokaryota. 1. Chroococcales. In Susswasserflora von Mirreleuropa; Bd. 19/1. Jena; Gustav Vischer Verlag: 1998; p. 548.

19. Komárek, J.; Anagnostidis, K. Cyanoprokaryota. Teil 2. Oscillatoriales. Süßwasserflora von Mitteleuropa 19/2; Elsevier: München, Germany, 2005; pp. 1-759.

20. Prygiel, J.; Coste, M. Guide methodologique pour la mise en oeuvre de l'Indice Biologique Diatomées; Agences de l'Eau Cemagref: Bordeaux, France, 2000; pp. 1-134.

21. Guiry, M.D.; Guiry, G.M. AlgaeBase. World-Wide Electronic Publication, National University of Ireland, Galway. 2021. Available online: http://www.algaebase.org (accessed on 25 February 2021).

22. Tsarenko, P.M.; Wasser, S.; Nevo, E. (Eds.) Algae of Ukraine: Diversity, nomenclature, taxonomy, ecology and geography. Vol. 1. Cyanoprocaryota, Euglenophyta, Chrysophyta, Xanthophyta, Raphidophyta, Phaeophyta, Dinophyta, Cryptophyta, Glaucocystophyta and Rhodophyta. Gantner Verlag: Rugell, 2006; pp. 1-713; Vol. 2. Bacillariophyta. Ibid, 2009; pp. 1-413; Vol. 3. Chlorophyta. Ibid, 2011; pp. 1-511; Vol. 4. Charophycota. Ibid, 2014; pp. 1-703.

23. Hustedt, F. Die Diatomeenflora des Flüßsystems der Weser im Gebiet der Hansestadt Bremen. Abhandlungen Herausgegeben vom Naturwissenschaftlichen Verein zu Bremen 1957, 34, 181-440.

24. Sládeček, V. System of water quality from the biological point of view. Archiv für Hydrobiologie. Beiheft Ergebnisse der Limnologie 1973, 7, 1-218.

25. Van Dam, H.; Mertens, A.; Sinkeldam, J. A coded checklist and ecological indicator values of freshwater diatoms from the Netherlands. Neth. J. Aquat. Ecol. 1994, 28, 117-133.

26. Barinova, S.S.; Belous, Y.P.; Tsarenko, P.M. Algal indication of water bodies in Ukraine; Haifa University Press: Haifa, Israel; Kiev, Ukraine, 2019; pp. 1-367.

27. Bilous, O.P.; Barinova, S.S.; Ivanova, N.O.; Huliaieva, O.A. The use of phytoplankton as an indicator of internal hydrodynamics of a large seaside reservoir-case of the Sasyk Reservoir, Ukraine. Ecohydrol. Hydrobiol. 2016, 6, 160-174, doi:10.1016/j.ecohyd.2016.08.002.

28. Bilous, O.P.; Wojtal, A.Z.; Ivanova, N.O.; Tsarenko, P.M.; Burova, O.V.; Barinova, S.S. Benthic Diatom Composition in Coastal Zone of Black Sea, Sasyk Reservoir (Ukraine). Diversity 2020, 12, 458, doi:10.3390/d12120458.

29. Palamar-Mordvintseva, G.M. Desmidial algae of Ukrainian SSR (morphology, systematic, paths of evolution, flora and geographical distribution); Nauk. Dumka: Kiev, Ukraine, 1982; pp. 1-240.

30. Tsarenko, P.M.; Khudyi, A.M.; Tunovsky, J. 2016. On the structure of phyto- and zooplankton communities of Nesamovite Lake in the Ukrainian Carpathians. In Proceedings of the Lake Ecosystems: Biological Processes, Antropogenic Transformation, Water Quality: Materials of the V International Conference, 12-17 September 2016. Minsk-Naroch, Mikheeyeva, T.M.; Ed.; BSU: Minsk, Belarus, 2016; pp. 187-189.

31. Kryvosheia, O.M.; Tsarenko, P.M. Bacillariophyta in the High-Mountain Lakes of Chornogora Range in Ukrainian Carpathians. Int. J. Algae 2018, 20, 239-264, doi:10.1615/InterJAlgae.v20.i3.40.

32. Wasser, S.P.; Kondrat'eva, N.V.; Masyuk, N.P. (Eds.) Vodorosli: Spravochnik (Algae: A Reference Book); Naukova Dumka: Kiev, Ukraine, 1989; pp. 1-608. (In Russian)

33. Mykitchak, T.I. Transformation of ecosystems glacial lakes in Ukrainian Carpathians. Ecol. Noospherol. 2017, 28, 28-36, doi:10.15421/031713.

34. Romanenko, V.D.; Zhukynsky, V.M.; Oksiyuk, O.P.; Yatsyk, A.V.; Chernyavska, A.D.; Vasenko, O.G.; Vernichenko, G.A. Metodyka vstanovlennya i vykorystannya ekologichnykh normatyviv yakosti poverkhnevykh vod sushi ta estuariyiv Ukrayiny. [Procedure of the Determination and Use of Ecological Norms of the Quality of the Surface Waters of Land and Estuaries of Ukraine]; Minekoresursiv Ukrayiny Press: Kyiv, Ukraine, 2001; pp. 1-48. (In Ukrainian) 